Contributions:

A Study design/planning

B Data collection/entry

C Data analysis/statistic

D Data interpretation

E Preparation of manuscript

F Literature analysis/search

$\mathrm{G}$ Funds collection

\section{FREQUENCY FOLLOWING RESPONSES IN YOUNG, MIDDLE, AND LATE ADULTHOOD}

\author{
Nithin A.K. ${ }^{\text {A-F, }}$, Sinju P.K. ${ }^{\text {B-E }}$
}

Department of Audiology \& Speech Language Pathology, Mar Thoma College of Special Education, Badiadka, India

Corresponding author: Nithin A. K.; Department of Audiology \& Speech Language Pathology, Mar Thoma College of Special Education, Badiadka, Perdala (PO), Kasaragod

District, Kerala State 671551, email: nithinak22@gmail.com

\begin{abstract}
Introduction: Previous work using speech evoked ABR reported a significant decline in onset and offset responses with advancing age, but no differences for Frequency Following Responses (FFRs). Many researchers report reduced neural synchrony as age advances. The aim of this study was to investigate the effect of aging on FFRs.

Material and methods: A total of 45 participants were included in the study. They were divided into three groups of 15 individuals: young adults (20-40 years), middle aged adults (41-60 years), and older adults ( $>60$ years). All had normal hearing sensitivity and were free from any otologic or neurologic disorder. FFRs were obtained using a /da/ stimulus of $40 \mathrm{~ms}$ and $80 \mathrm{dBnHL}$ containing five formants. To minimize preferential recording of activity from either side, a midline electrode site was used. Data analysis followed Russo et al. [1]. The seven peaks of the response to /da/ (waves V, A, C, D, E, F, O) were identified by two experienced audiologists as onset responses, spectro-temporal responses, fundamental frequency, and harmonics.

Results: Findings were that the occurrence of waves V and A was 100\% in all individuals, but the occurrence of waves $\mathrm{C}$ and $\mathrm{O}$ was $60 \%$ in young adults, $73 \%$ in middle age adults, and $53 \%$ in older adults.

Conclusions: These findings suggest that older listeners have a general reduction in synchronous neural firing to speech stimuli. In particular, the ability of neurons in the auditory system to accurately encode important temporal features of speech may in older adults be limited by impaired neural synchrony, slowed neural conduction time, reduced phase locking ability, or other mechanisms.

Key words: frequency following responses • speech stimulus • onset and offset responses • spectro-temporal features • neuronal synchrony

\section{POTENCJAŁY WYWOŁANE PODĄŻAJĄCE ZA CZĘSTOTLIWOŚCIĄ WE WCZESNYM, ŚREDNIM I PÓŹNYM WIEKU DOJRZAŁYM}

\title{
Streszczenie
}

Wprowadzenie: Wcześniejsze prace z wykorzystaniem słuchowych potencjałów pnia mózgu (ABR) wywołanych mową wskazywały na znaczny spadek odpowiedzi onset $\mathrm{i}$ offset wraz z wiekiem, przy braku różnic w potencjałach wywołanych podążających za częstotliwością (FFR). Wielu naukowców donosi, że synchronizacja neuronalna zmniejsza się wraz z wiekiem. Celem badania było poznanie wpływu starzenia się na potencjały wywołane podążające za częstotliwością (FFR).

Materiał i metody: W badaniu wzięło udział 45 osób, które zostały podzielone na trzy grupy po 15 osób: młodzi dorośli (20-40 lat), dorośli w średnim wieku (41-60 lat) i starsi dorośli (>60 lat). U wszystkich uczestników czułość słuchu była w normie, badani nie mieli też żadnych zaburzeń otologicznych ani neurologicznych. FFR były wywoływane bodźcem /da/ trwającym $40 \mathrm{~ms}$ na poziomie $80 \mathrm{~dB} \mathrm{nHL}$ zawierającym pięć formantów. W celu zminimalizowania uprzywilejowania rejestracji zapisu aktywacji z jednej strony elektroda została zamocowana w linii środkowej. Analizę danych przeprowadzono metodą opisaną przez Russo et al. [1]. Siedem szczytów odpowiedzi na /da/ (fale $\mathrm{V}, \mathrm{A}, \mathrm{C}, \mathrm{D}, \mathrm{E}, \mathrm{F}, \mathrm{O}$ ) zostało zidentyfikowanych przez dwóch doświadczonych audiologów - jako odpowiedzi onset, odpowiedzi częstotliwościowo-czasowe, składowa podstawowa i harmoniczne.

Wyniki: Wyniki badania pokazały, że fale V i A były obecne u wszystkich uczestników (100\%), ale fale C i O występowały u $60 \%$ młodych dorosłych, $73 \%$ dorosłych w średnim wieku i 53\% starszych dorosłych.

Wnioski: Badania te sugerują, że u osób starszych występuje ogólne pogorszenie synchronicznej pracy neuronów w odpowiedzi na bodźce mowy. W szczególności zdolność neuronów w układzie słuchowym do dokładnego kodowania ważnych czasowych cech mowy może być u osób starszych ograniczona przez słabą synchronizację neuronalną, spowolniony czas przewodzenia nerwowego, zmniejszoną zdolność synchronizacji fazy lub inne mechanizmy.

Słowa kluczowe: bodziec słowny • odpowiedzi onset i offset $\bullet$ charakterystyka częstotliwościowo-czasowa $\bullet$ synchronizacja neuronalna • potencjały wywołane podążające za częstotliwością

\section{Introduction}

Aging is usually associated with the global decline in all the cognitive processes including memory, thinking, and sensory ability. The speech understanding difficulties expressed by older adults are likely to arise from a number of different sources. From the cochlea to the brain, numerous structural and chemical changes take place with advancing age [2]. These physiological changes alter the way frequency and timing information is encoded in the peripheral and central auditory systems. 
The FFR is an evoked potential generated by periodic or nearly-periodic auditory stimuli [3]. In response to a consonant-vowel syllable, the onset response (waves V, A) represents the burst onset of a voiced consonant, whereas later portions likely represent the offset of the onset burst or the onset of voicing (wave C) and the offset of the stimulus (wave $\mathrm{O}$ ). The harmonic portion of the speech stimulus gives rise to the FFR (waves D, E, and F) [4,5]. The FFR is a series of transient neural events phase-locked to the periodic information within the stimulus [6,7]. Disruption of either the onset or the offset in the FFR is likely to result in impaired representation of important segmental and suprasegmental information within the speech sound, thus degrading the input to higher levels of the auditory system [8].

Clinard et al. [9] have recorded FFRs in the older age group by using simple pure tones of different frequencies. They report that as the age advances there is a reduction in the amplitude of the FFR for and near a $1000 \mathrm{~Hz}$ pure tone. In another study, Vander et al. [10] reported that there were significant age-related changes observed for onset latencies and offset latencies, as well as reduced amplitudes.

\section{Material and methods}

\section{Participants}

Participants were selected by non-random convenient sampling. A total of 45 participants (90 ears) were included. They were divided into three groups each of 15 participants (30 ears). The age range for each group was 20-40 years (early adulthood), 40-60 years (middle adulthood), and 60 years and above (late adulthood) according to the classification by Kaplan and Sadock [11]. Inclusion criteria were normal hearing sensitivity with thresholds within $25 \mathrm{dBHL}$ for octave frequencies from 0.25 to $4 \mathrm{kHz}$, with 'A' type tympanograms and normal middle ear reflexes. Individuals with otologic and neurologic history were excluded. Informed consent was obtained from all the participants prior to the study.

\section{Instruments}

A calibrated GSI 61 diagnostic audiometer was used to estimate pure-tone thresholds and a calibrated middle ear analyzer (GSI Tympstar) was used for tympanometry and reflexometry.

An IHS Smart EP v. 3.92 (Intelligent Hearing Systems, Florida, USA) was used to record and analyse speech evoked ABR. Matlab (v. 7) was used to analyse fundamental frequency, harmonic responses, and overall RMS from the ABR response waveform.

\section{Procedure}

All tests were conducted in sound proof rooms in the Department of Audiology and Speech Language Pathology at Kasturba Medical College, Mangalore. Pure tone threshold was obtained using a modified version of the Hughson and Westlake procedure [12] across octave frequencies from 0.25 to $8 \mathrm{kHz}$ for air conduction and from 0.25 to $4 \mathrm{kHz}$ for bone conduction. The status of the middle ear was evaluated using tympanometry and reflexometry for 0.5 and $1 \mathrm{kHz}$ using a $226 \mathrm{~Hz}$ probe tone.

The speech stimulus /da/ was used to evoke the FFR (with permission from North-Western University). To synthesize the stimulus, a Klatt cascade/parallel formant synthesizer was used at a sampling rate of $10 \mathrm{kHz}$. The stimulus was $40 \mathrm{~ms}$ in duration and consisted of five formants with an onset burst during the first $10 \mathrm{~ms}$ at F3, F4, and F5, followed by $30 \mathrm{~ms} \mathrm{~F} 1$ and F2 transitions ceasing immediately before the steady-state portion of the vowel. Acoustically, the fundamental frequency (F0) of the stimulus /da/ was ramped from 100 to $120 \mathrm{~Hz}$. The test stimuli were delivered through Etymotic ER-3 earphones at an intensity of $80 \mathrm{dBnHL}$. This presentation level was chosen so that the stimulus was almost always well above detection threshold but still within a comfortable range, since responses near threshold are often weak and require many repeated sweeps to yield a robust signal. A repetition rate of 7.1/ sec was used because the majority of studies have used this as their lowest rate. In order to minimize the preferential recording of activity from either side, a midline electrode site was used. The non-inverting electrode was placed on the vertex, the inverting electrode on the midline of the nape of the neck, and ground on the nasion.

Before placing the electrodes, the electrode sites were cleaned using skin preparation paste and the electrodes were placed with Ten-20 conduction paste. Electrode impedance was checked to ensure it was less than $3 \mathrm{kohm}$ at each electrode site. The recording parameters are listed in Table 1.

Table 1. Recording parameters for FFR

\begin{tabular}{lc}
\hline Stimulus & Speech burst $/ \mathrm{da} /$ \\
\hline Total number of sweeps & 4000 \\
\hline Rate & $7.1 / \mathrm{s}$ \\
\hline Polarity & Alternating \\
\hline Intensity & $80 \mathrm{dBnHL}$ \\
\hline Filters & $50-1500 \mathrm{~Hz}$ \\
\hline Amplification & 50000 \\
\hline Analysis time window & $70 \mathrm{~ms}(10 \mathrm{~ms}$ pre stimulus \\
\hline Notch filter & and $\mathrm{ms}$ post stimulus) \\
\hline Channels & On \\
\hline
\end{tabular}

FFRs were recorded twice for both ears to ensure reliability of the waveforms and to get a weighted average waveform for the speech stimulus. Two expert audiologists analysed the data for onset, spectro-temporal features, and offset responses.

\section{Data analysis}

Data analysis was done as described by $[1,13,14]$. The seven peaks of the response to /da/ $(\mathrm{V}, \mathrm{A}, \mathrm{C}, \mathrm{D}, \mathrm{E}, \mathrm{F}, \mathrm{O})$ were identified by the audiologists. The ear of presentation was not disclosed to them. The identified peaks were further 
categorized as onset responses, spectro-temporal responses, fundamental frequency, and harmonics. These terms are described as follows.

Onset response: The onset burst contains broad frequency information and elicits wave $\mathrm{V}$ as well as a following trough, known as wave A. These peaks are comparable to the click evoked wave V and Vn.

Spectro-temporal measures: Waves D, E, and F arise in response to the fundamental periodicity of the stimulus and approximate its fundamental frequency. They also correspond to the voiced portion of the syllable. The latencies of these peaks are the composite spectro-temporal measures.

Fundamental frequency response: The average spectral amplitude was calculated for a range encompassing the fundamental frequency (F0) of 103-120 Hz using the amplitude of F0 and the interpeak intervals between peaks D and E, and $\mathrm{E}$ and $\mathrm{F}$. These interpeak intervals mimic the fundamental periodicity of the stimulus and reflect F0 encoding. Analysis of F0 was done between 11.4 and 47 ms.

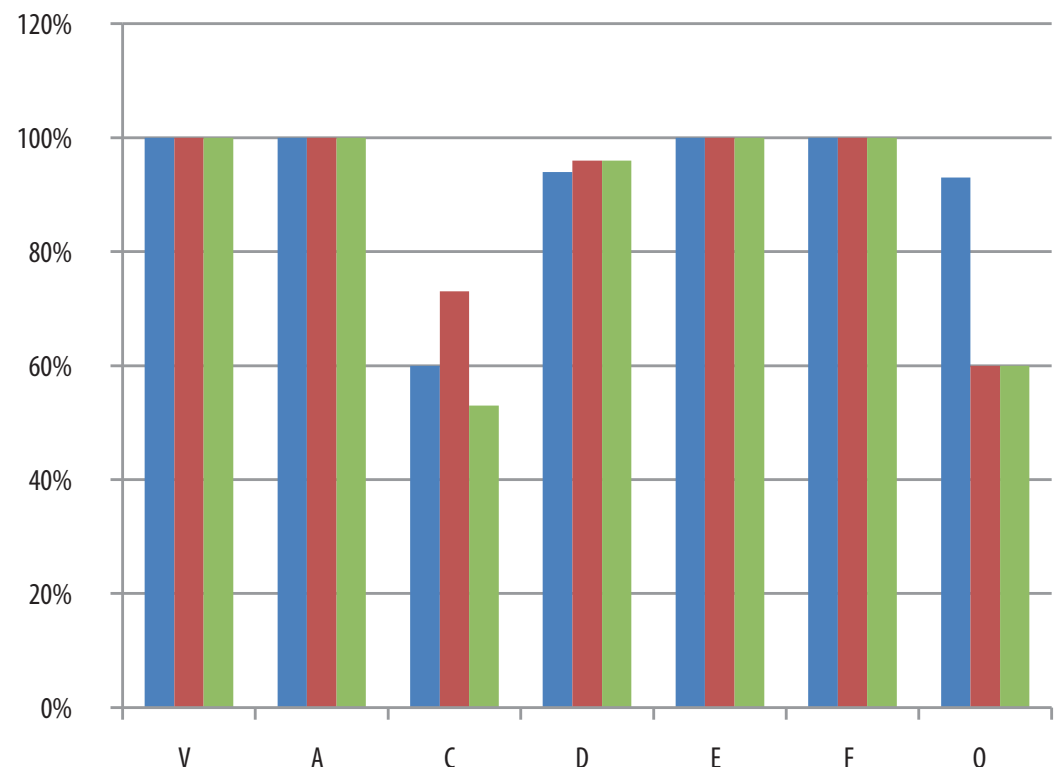

Figure 2. Occurrence of different waves in FFR

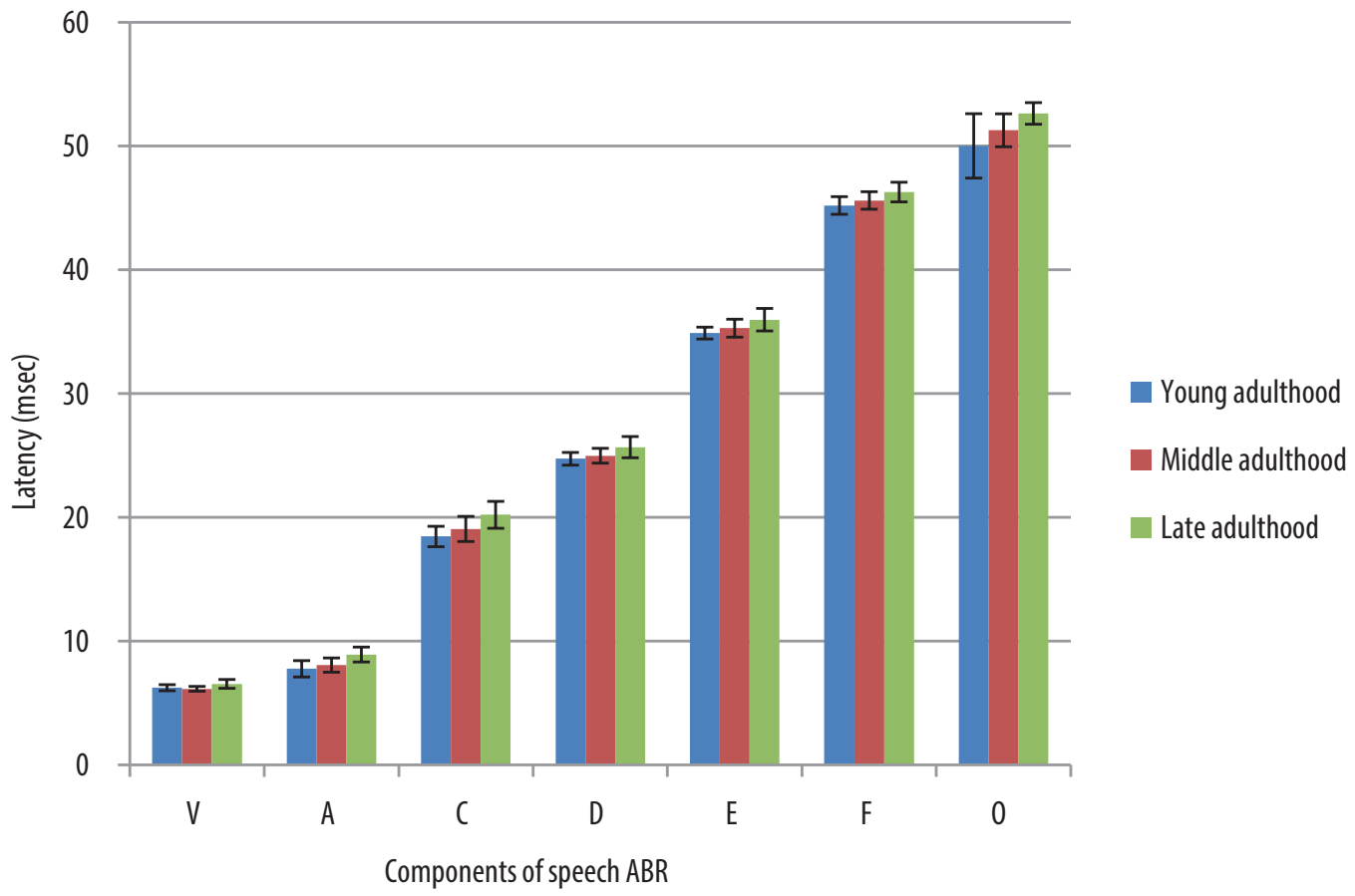

Figure 3. Mean and standard deviation of FFR latencies 
Harmonics: The harmonics measure is a composite of the average spectral energy over two frequency bands: the first formant (F1) of 455-720 Hz, and high frequency (HF) of 721-1154 Hz. F1 includes the harmonics of the stimulus that make up the most prominent frequencies of the first formant. The HF range is composed of harmonics between the first and second formants (F1 and F2). Because F2 and higher formants are above the phase locking limits of the brainstem, no higher frequency ranges were included. The overall RMS values were also extracted from the FFR responses.

Offset response: The offset response is known as "O" and relates to the cessation of the stimulus.

\section{Statistical analysis}

ANOVA (Fisher's test) for group comparison and a Bonferroni test for intergroup comparison were employed for statistical analysis of the responses.

\section{Results}

The present study compared the latencies of onset and sustained responses as well as the amplitudes of onset and sustained responses across different age groups (young, middle, and late adulthood) from the FFR. Specifically, the FFR responses were onset responses ( $\mathrm{V}$ and $\mathrm{A}$ ), transition response $(\mathrm{C})$, sustained responses $(\mathrm{D}, \mathrm{E}$, and $\mathrm{F})$, and offset response $(\mathrm{O})$.

\section{Occurrence of FFRs across age groups}

Figure 2 shows that the occurrence of waves $\mathrm{V}$ and $\mathrm{A}$ was $100 \%$ in all individuals. The occurrence of wave $\mathrm{C}$ was $60 \%$ in young adults, $73 \%$ in middle aged adults, and $53 \%$ in the elderly.

The occurrence of wave D was $93 \%$ in young adults, $97 \%$ in middle age, and $97 \%$ in the elderly. The occurrence of waves $\mathrm{E}$ and $\mathrm{F}$ was $100 \%$ in all three groups. The wave O occurrence was $93 \%$ in young age, and $60 \%$ in both middle and elderly individuals.

\section{Age related changes in FFR in adults with nor- mal hearing}

Waves $\mathrm{V}$ and $\mathrm{A}$ were observed at an onset of less than $10 \mathrm{~ms}$. Wave C latency was observed near 19-20 ms, and the latency of D, E, F was observed to be in the range of 24 to $47 \mathrm{~ms}$. Offset response as $\mathrm{O}$ occurred at around 51-52 ms. Figure 3 shows that latency of FFR (V, A, C, D, $\mathrm{E}, \mathrm{F}$, and $\mathrm{O}$ ) is almost the same in young adults and the middle aged group.

Table 2 shows $F$-values, with degrees of freedom and level of significance, for peak latency, amplitude, and harmonics of the FFR. One-way ANOVA showed a main effect on age on FFR latencies for all the peaks (V, A, C, D, E, F, O).

A post hoc Bonferroni test was administered to see whether there were significant differences in pairwise comparisons between the three groups, and the results showed that there was a significant difference $(p<0.05)$ in peak latencies of all the components of the FFR between young adults and the elderly. Similarly, there was a significant difference $(p<0.05)$ in peak latencies of V, A, C, D, E, and F between the middle aged and the elderly. However, there was no significance difference for latency of the $\mathrm{O}$ peak between the middle age group and the elderly group.

Figure 5 shows the mean and standard deviation of peak amplitude of V, A, C, D, E, F, and O. The amplitude of peaks obtained for all peaks lay between -1 to $1 \mu \mathrm{V}$. Mean amplitude showed that as age advances, there was a reduction in amplitude for all the peaks. Standard deviations were observed to be greater for all components of the speech evoked ABR. One-way ANOVA showed a main effect of age on FFR for all peaks (V, A, C, D, E, F, O). A Bonferroni test was done to see if there were significant differences between pair-wise comparisons of the three groups. There was a significant difference $(p<0.05)$ in peak amplitude of all components of the speech evoked ABR between young adults and the elderly. When the comparison was made between middle aged and the elderly, the results showed that there was a significant difference in amplitude of waves $\mathrm{V}, \mathrm{A}, \mathrm{C}$,

Table 2. F-values and levels of significance for peak latencies, amplitudes, and harmonics of FFR

\begin{tabular}{lcc}
\hline Component & F value & Level of significance \\
\hline V (latency and amplitude) & $F(2,87)=17.29,9.02$ & $p<0.05$ \\
\hline A (latency and amplitude) & $F(2,87)=28.51,5.02$ & $p<0.05$ \\
\hline C (latency and amplitude) & $F(2,53)=13.83,28.51$ & $p<0.05$ \\
\hline D (latency and amplitude) & $F(2,83)=15.02,14.08$ & $p<0.05$ \\
\hline E (latency and amplitude) & $F(2,87)=17.05,8.01$ & $p<0.05$ \\
\hline F (latency and amplitude) & $F(2,87)=16.48,16.48$ & $p<0.05$ \\
\hline O (latency and amplitude) & $F(2,61)=10.29,4.06$ & $p<0.05$ \\
\hline F0 & $F(2,87)=7.55$ & $p<0.05$ \\
\hline F1 & $F(2,87)=10.72$ & $p<0.05$ \\
\hline HF & $F(2,87)=15.19$ & $p<0.05$ \\
\hline RMS & $F(2,87)=3.93$ & $p<0.05$ \\
\hline
\end{tabular}



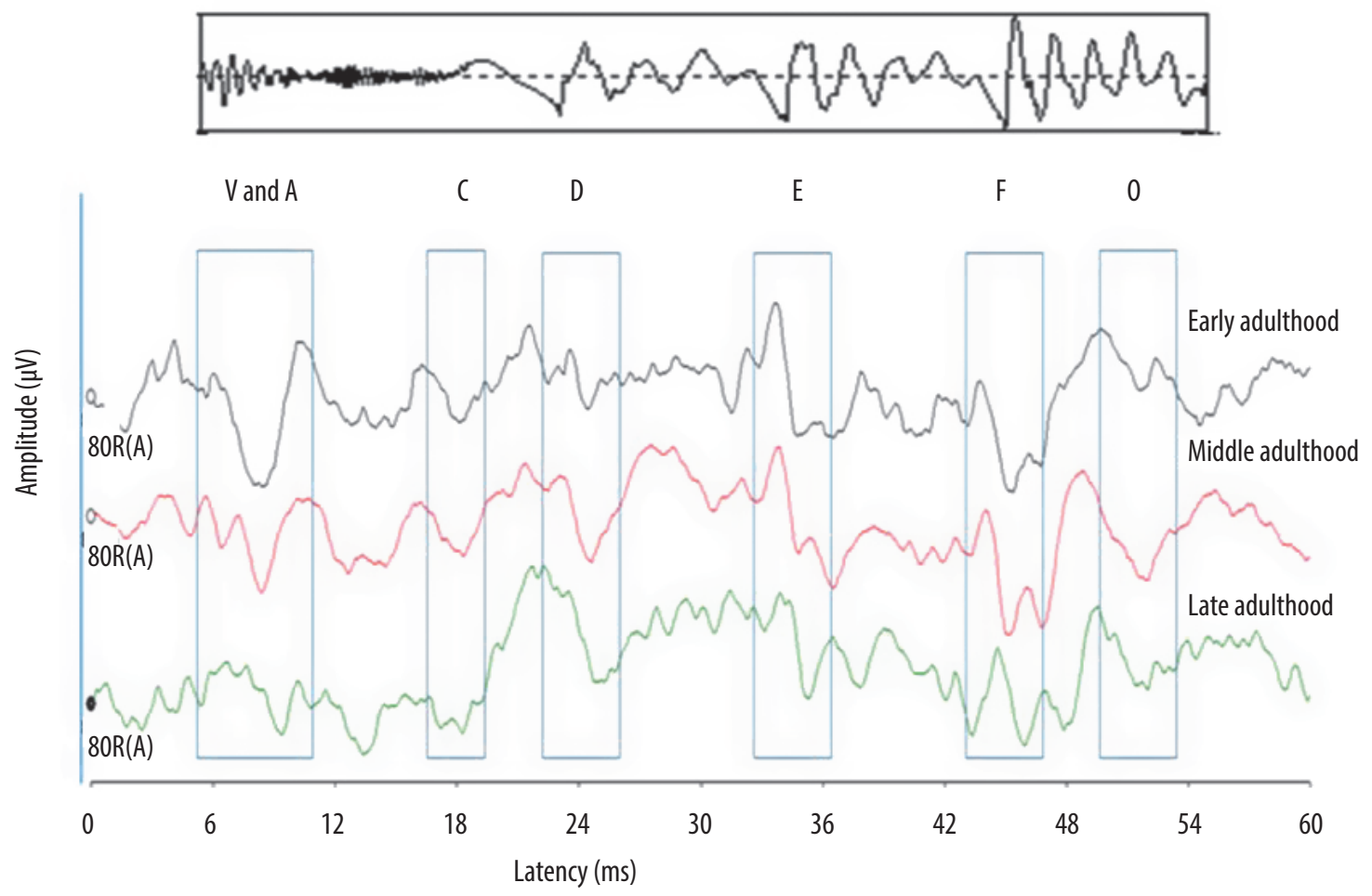

Figure 4. Grand average waveforms of the FFR for all three age groups

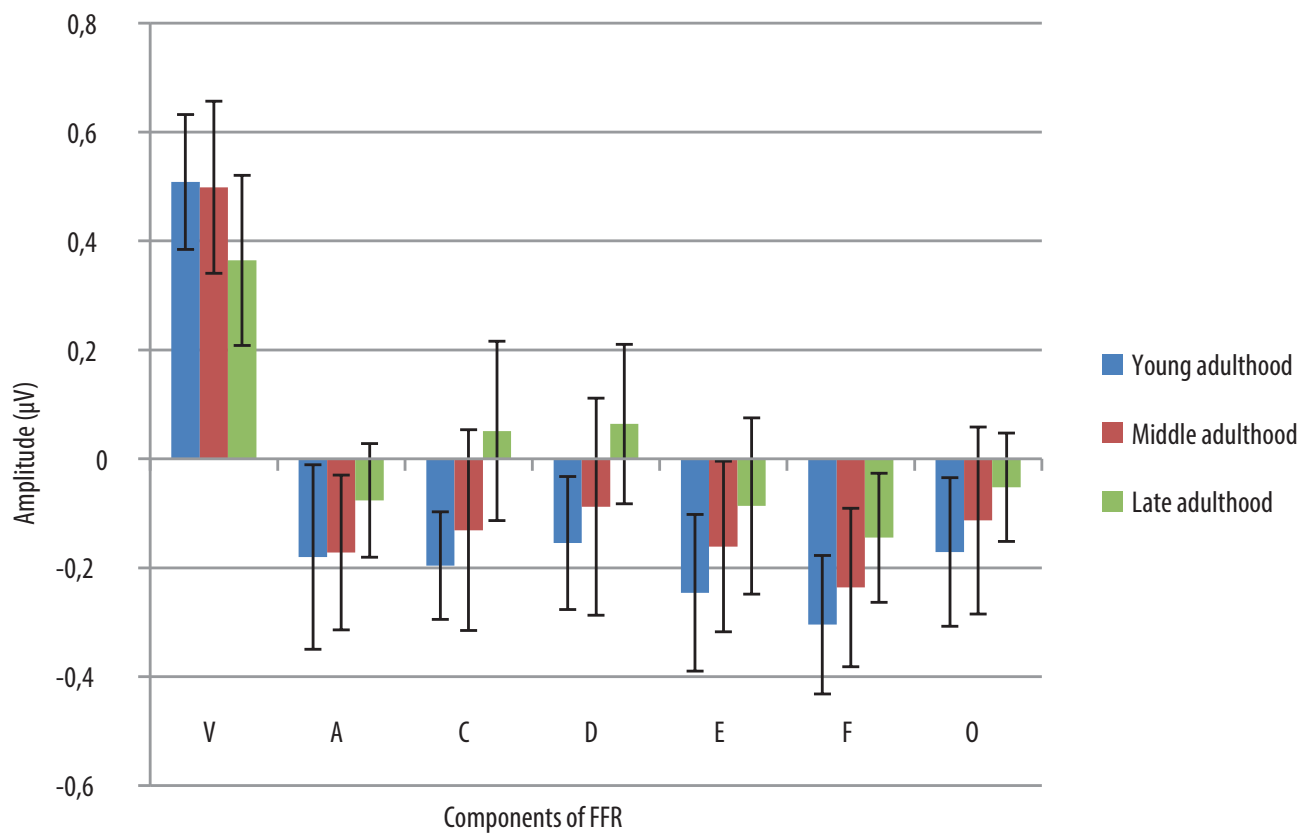

Figure 5. Mean and standard deviation for amplitude of FFR

$D$, and $\mathrm{F}$. However, the amplitudes of waves $\mathrm{E}$ and $\mathrm{O}$ was not significantly different $(p>0.05)$ between middle aged adults and the elderly.

Figure 6 shows the mean and standard deviation of encoding of F0, F1, HF, and RMS from the FFR. It was observed that the amplitude of F0 was greater than the other harmonics.
As age advanced, there was a decrease in mean amplitude of F0, F1, HF, and RMS.

One-way ANOVA showed the main effect of age on amplitude of FFR for all components (F0, F1, HF, and RMS). For pair-wise comparison, a Bonferroni test showed that there was a significant difference $(p<0.05)$ between young adults 


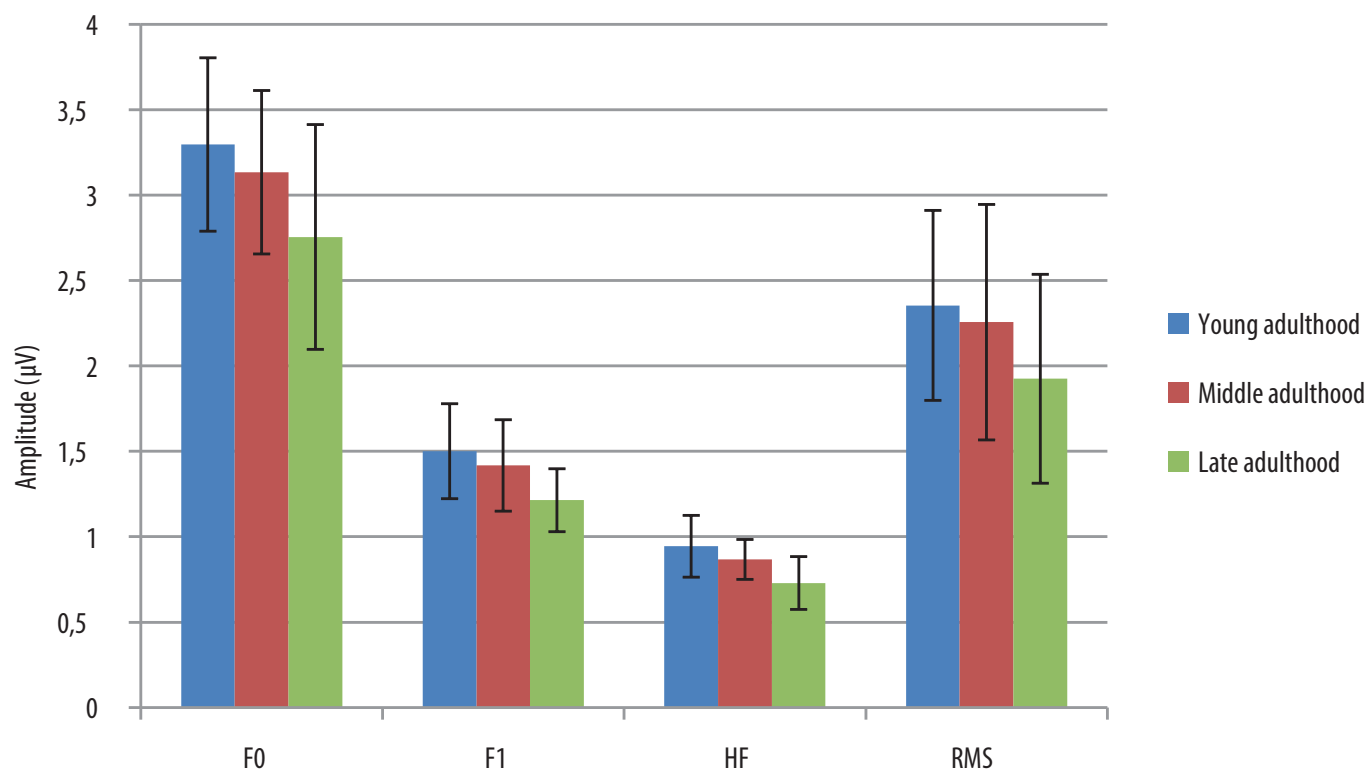

Figure 6. Mean and standard deviation of fundamental frequency and harmonics for FFR

and the elderly for F0, F1, HF, and RMS. When the comparisons were made between middle-aged adults and the elderly, the results showed that there was a significant difference $(p<0.05)$ in the amplitude of F0, F1, and HF. However, the difference in amplitude of RMS was not statistically significant $(p>0.05)$ between the middle aged adults and the elderly.

\section{Discussion}

the present study was carried out to find the effect of aging on FFRs in adults of different ages having normal hearing sensitivity. Consistent with the growing evidence of age-related effects on the central and peripheral auditory systems in elderly listeners, it was expected that the FFR would show evidence of age-related differences in amplitude and timing because of a reduced ability to accurately encode rapidly changing spectro-temporal features of speech. The results of the present study support this hypothesis. Only a few studies have focused on FFR across ages, with the most reported population being young adults [15].

The percentage occurrence of FFR peaks was evaluated for all three age groups. It was observed that the occurrence of all peaks was the same across all three age groups, except for waves $\mathrm{C}$ and $\mathrm{O}$. The occurrence of waves $\mathrm{C}$ and $\mathrm{O}$ became smaller from young adulthood to old age. Elliott et al. [16] reported similar findings behaviourally in the elderly: old age participants showed poorer perception of transition duration compared to young adults, and they required longer transition duration than younger participants. These differences in processing transition duration may be because of its dynamic nature. In the transition period there are variations in spectral and temporal cues as the stimulus shifts from speech burst to formant frequency. The reduction in the occurrence of peak $\mathrm{C}$ in late adulthood is consistent with studies that note changes in the auditory system with advancing age.
The reduction in the occurrence of wave $\mathrm{O}$ in older individuals likely reflects reduced synchrony, since offset components of the FFR in response to various longer duration stimuli probably represent a synchronous decrease in firing rate at the end of the stimulus [17]. Another explanation for the reduction in occurrence may be deficient encoding by specialized offset-type or duration-sensitive neurons $[18,19]$; these cited studies report a loss of neurons in the ventral cochlear nucleus, and altered size and shape of the ganglion cells in the medial geniculate body, the superior olivary nucleus, and the inferior colliculus. They also report atrophy in the eighth cranial nerve. Consequently, the reduction in the occurrence of waves $\mathrm{C}$ and $\mathrm{O}$ in late adulthood which we saw might be attributed to these altered neuronal processes in the peripheral and central auditory systems. Further study has also shown that elderly subjects have an increase in latency of all waves compared to younger adults. Aging causes a progressive loss of structure or neuronal functioning which can be seen as reduced auditory evoked potentials. Through the FFR, it is also seen that there is a reduction in the speed of neural activation from brainstem to cortical structures [20].

The present study contributes to our understanding of the FFR in evaluating the effects of advancing age on subcortical portions of the central auditory system. A similar study was done by Vander-Werff et al. [10], who evaluated FFRs in young and old subjects. The results showed a significant difference in latency for wave $\mathrm{O}$ and $\mathrm{F}$; however, other waves (V, A, C, D, and F) showed no significant difference in latency. The amplitude of waves $\mathrm{V}, \mathrm{A}$, and $\mathrm{O}$ was observed to be significantly different between young and old age groups. The results of the present study with onset and offset response are in good general agreement with these observations. Reduced amplitude and delayed latencies of some or all onset and offset components were observed in old age individuals. These reduced amplitudes and delayed latencies with increased age can 
be attributed to a reduction in synchronous neural firing to transient changes in speech and impaired neural coding of the duration and offset of a stimulus in the aging auditory system.

Although the onset and offset responses represent synchronous neural firing to transient events in the stimulus, the sustained portion of the FFR provides information about neural phase-locking to the fundamental frequency and harmonic content of the stimulus. The present results show that there is a significant difference in transition (C) and sustained portion responses (D, E, and F) in terms of latencies and amplitudes of the FFR with advancing age. Similarly, Clinard et al. [9] reported significantly reduced FFR amplitude for simple tonal stimuli with advancing age. They reported significant differences near the $1000 \mathrm{~Hz}$ signal. Older subjects in this study also showed evidence of reduced phase-locking to the fundamental and harmonic components of speech, as measured by reduced spectral amplitude for F0, F1, and HF. Overall, RMS was also observed to be significantly different with advancing age. In the present study significant age-related changes in latencies and amplitude occurred due to a decline in phase-locking ability in the brainstem. However, reduced neural synchrony might also result from peripheral and/or central auditory changes with age. For example, impaired neural synchrony may involve age-related changes in physiology such as metabolic activity in the cochlea [21], levels of inhibitory neurotransmitters [22], or a decrease in the number of cells in the auditory nuclei [23].

In contrast to the present study, Vander-Werff et al. [10] reported no significant difference in latency and amplitude of the transition region or sustained portion in old age individuals. They also did not observe any difference in spectral amplitude between the age groups. The significant differences in the transition and sustained responses observed in the present study are not compatible with the observations of the earlier study [10]. They reported no difference due to inter-individual variability in response or to the accurate identification of peaks. Some individuals had responses of poor or complex morphology, which may have been contaminated by background noise or muscle artifact. Older adults tend to have higher levels of muscle artefact. However, in the present study these differences might have been due to the mean pure tone average threshold for young and middle age group, which was around 7-8 dBHL, as compared to old age group who had a level of around 22-23 dBHL. Another reason may be that in our study $80 \%$ of the participants were 70 years or older.

From the present study, we conclude that the reduced amplitudes and delayed latencies in the FFR with increasing age seem to be consistent with a reduction in neural firing to onset and transient changes in speech and impaired neural encoding of the duration of a stimulus in the aging auditory system. Such reduced accuracy in encoding of rapidly changing transient cues, such as those marking syllable transitions could, at the brainstem level, result in significant impairment to the older individual's ability to understand rapid or reverberant speech or separate speech from background noise.

Further study might involve comparing speech recognition abilities and FFR correlation in young and old age groups. Research could also study the relationship between neural processing of speech at the brainstem level and higher level processing in older adults, thereby improving our understanding of the underlying mechanism of age-related auditory processing.

\section{Conclusions}

The present study has investigated the effect of aging on different components of the FFR. The results reveal that with increasing age, the occurrence of waves $\mathrm{C}$ and $\mathrm{O}$ was reduced from young adulthood to old age. These findings suggest that older listeners have a general reduction in synchronous neural firing to speech stimuli. In particular, the ability of neurons in the auditory system to accurately encode important temporal features of speech may be limited by impaired neural synchrony, slowed neural conduction time, reduced phase locking ability, or other mechanisms in older adults.

\section{References}

1. Russo N, Nicol T, Musacchia G, Kraus N. Brainstem responses to speech syllables. Clin Neurophysiol, 2004; 115: 2021-30.

2. Willott JF. Aging and the Auditory System. San Diego: Singular Publishing, 1991.

3. Worden FG, Marsh JT. Frequency-following (microphonic-like) neural responses evoked by sound. Electroencephalogr Clin Neurophysiol, 1968; 25(1): 42-52.

4. Galbraith G, Arbagey P, Branski R, Comerci N, Rector P. Intelligible speech encoded in the human brain stem frequency-following response. Neuropsychologia, 1995; 6: 2363-7.

5. Krishnan A. Human frequency-following responses: representation of steady-state synthetic vowels. Hear Res, 2002; 166, 192-201.

6. Marsh JT, Worden FG. Sound evoked frequency following responses in the central auditory pathway. Laryngoscope, 1968; 78: 1149-63.
7. Sohmer H, Pratt H. Identification and separation of acoustic frequency following responses (FFRs) in man. Electroencephalogr Clin Neurophysiol, 1977; 42(4): 493-500.

8. Kraus N, Nicol T. Brainstem origins for cortical 'what' and 'where' pathways in the auditory system. Trends Neurosci, 2005; 28, 176-181.

9. Clinard CG, Tremblay KL, Krishnan AR. Aging alters the perception and physiological representation of frequency: evidence from human frequency-following response recordings. Hear Res, 2010; 264: 48-55.

10. Vander-Werff RK, Burns KS. Brainstem responses to speech in younger or older adults. Ear Hear, 2011; 32(2), 168-80.

11. Kaplan HI, Sadock VA. Synopsis of Psychiatry: Behavioral sciences/clinical psychiatry (10th ed.). Philadelphia: Lippincott Williams and Wilkins, 2007.

12. Carhart R, Jerger JF. Preferred method for clinical determination of pure-tone thresholds. J Speech Hear Disorders, 1959; 24: $330-45$. 
13. Wible B, Nicol T, Kraus N. Atypical brainstem representation of onset and formant structure of speech sounds in children with language-based learning problems. Biol Psychol, 2004; 67(3), 299-317.

14. Dhar S, Abel R, Hornickel J, Nicol T, Skoe E, Zhao W, Kraus N. Exploring the relationship between physiological measures of cochlear and brainstem function. Clin Neurophysiol, 2009;120: 959-66.

15. Sanfins M, Colella-Santos M. A review of the clinical applicability of speech-evoked auditory brainstem responses. J Health Sci, 2016; 6(1): 9-16.

16. Elliott LL, Hammer MA, Scholl ME, Wasowicz JM. Age differences in discrimination of simulated single-formant frequency transitions. Percept Psychophys, 1989; 46(2): 181-6.

17. Brinkmann RD, Scherg M. Human auditory on-off potentials of the brainstem. Scand Audiol, 1979; 8: 27-32.

18. Van Campen LE, Hall JW, Grantham DW. Human offset auditory brainstem response: effects of stimulus acoustic ringing and rise-fall time. Hear Res, 1997; 103: 35-46.
19. Johnson KL, Nicol TG, Zecker SG et al. Auditory brainstem correlates of perceptual timing deficits. J Cog Neurosci, 2007; 19: 376-85.

20. Hatzopoulos S, Ciorba A, Skarzynski PH (eds.). The Human Auditory System: Basic features and updates on audiological diagnosis and therapy. Intech Open, 2020.

21. Mills JH, Schmeidt RA, Schulte BA, Dubno JR. Age-related hearing loss: a loss of voltage, not hair cells. Semin Hear, 2006; 27: 228-36.

22. Caspary DM, Schatteman TA, Hughes LF. Age-related changes in the inhibitory response properties of dorsal cochlear nucleus output neurons: role of inhibitory inputs. J Neurosci, 2005; 25(47): 10952-9.

23. Frisina RD. Subcortical neural coding mechanisms for auditory temporal processing. Hear Res, 2001; 158: 1-27. 